\title{
DISMINUCIÓN DE LA
} FECUNDIDAD Y CAMBIOS EN LAS NECESIDADES INSATISFECHAS DE PLANIFICACIÓN FAMILIAR EN LOS PAÍSES DE AMÉRICA LATINA Y EL CARIBE

Javiera Fanta Garrido ${ }^{1}$

${ }^{1}$ Grupo desigualdad y movilidad social, Instituto de Investigaciones Gino Germani/CONICET. Psicóloga y doctoranda en Demografía (UNC). Egresada de Maestría en Políticas de Migraciones (UBA) y Especialización en Derechos Humanos, Migración y Asilo (UNLA). Ha trabajado como coordinadora de proyectos en el ámbito de la sociedad civil con población migrante.

Actualmente es becaria doctoral de CONICET e investiga las desigualdades reproductivas de migrantes limítrofes en Argentina. Otros temas de investigación son salud e interculturalidad, fecundidad adolescente y Derechos Sexuales y Reproductivos.

Trabajo recibido: 18 de Abril de 2017. Aprobado: 19 de Agosto de 2017.
FERTILITY DECLINE AND CHANGES IN UNMET NEED FOR FAMILY PLANNING IN COUNTRIES OF LATIN AMERICA AND THE CARIBBEAN

DECLÍNIO DA FERTILIDADE E MUDANÇAS NAS NECESSIDADES INSATISFEITAS DE PLANEJAMENTO FAMILIAR NOS MUNICÍPIOS DA AMÉRICA LATINA E CARIBE

\section{Resumen}

Desde la década de 1960, los niveles de fecundidad disminuyeron abruptamente en los países de América Latina y el Caribe (ALC). Mientras que la teoría de la transición demográfica clásica atribuye esta caída al desarrollo económico, las tendencias declinantes observadas en la región resultan ser mejor explicadas por el creciente uso de técnicas para el control de los nacimientos. El objetivo de este trabajo es examinar los cambios en las necesidades insatisfechas de planificación familiar en ocho países de ALC y determinar hasta qué punto sus variaciones han contribuido a alcanzar menores niveles de fecundidad desde 1990 hasta la actualidad. Los datos fueron derivados de Encuestas de Demografía y Salud y de Encuestas de Salud Reproductiva efectuadas a nivel nacional. Basado en la definición revisada de necesidad insatisfecha, utilizada para monitorear el 
ODM5, este artículo presenta un análisis descriptivo de los cambios en esta variable en los países involucrados y examina la relación entre la caída de la fecundidad y las necesidades insatisfechas de planificación familiar mediante un análisis de regresión. Los resultados muestran que todos los países registran porcentajes decrecientes de necesidad insatisfecha a lo largo del tiempo y que existe una asociación positiva entre la caída de la fecundidad y las necesidades insatisfechas de planificación familiar..

Palabras clave: planificación familiar; necesidades insatisfechas; fecundidad; contracepción.

\section{Abstract}

Since the 1960s, fertility levels dropped sharply in countries of Latin America and the Caribbean (LAC). While the classical demographic transition theory attributes this decline to economic development, the downward trends in the region are better explained by the increasing use of birth control technologies. The aim of this research is to examine changes of unmet need for family planning in eight countries of LAC and determine to what extent variations in unmet need have contributed to achieve lower fertility levels from 1990 to the present. Data was derived from Demographic and Health Surveys and Reproductive Health Surveys nationally representative. Based on the revised definition of unmet need used to monitor the MDG5, this article presents a descriptive analysis of changes in unmet need in each country and analyses the relationship between fertility decline and unmet need through regression analysis. Results show that all countries record decreasing percentages of unmet need over time and that fertility decline is positively associated with unmet need.

Key words: Family planning; unmet need; fertility; contraceptive use.

\section{Resumo}

Desde a década de 1960, os níveis de fertilidade diminuíram acentuadamente nos países da América Latina e do Caribe (ALC). Enquanto a teoria clássica da transição demográfica atribui essa queda ao desenvolvimento econômico, as tendências decrescentes observadas na região são melhor explicadas pelo uso crescente de técnicas de controle de natalidade. $\mathrm{O}$ objetivo deste trabalho é examinar as mudanças nas necessidades de planejamento familiar não atendidas em oito países da ALC e determinar em que medida suas variações contribuíram para menores níveis de fertilidade de 1990 para o presente. Os dados foram derivados de pesquisas demográficas e de saúde e pesquisas nacionais sobre saúde reprodutiva. Com base na definição revisada de necessidade insatisfeita, usada para monitorar o ODM5, este artigo apresenta uma análise descritiva das mudanças nessa variável nos países envolvidos e examina a relação entre a queda da fertilidade e a necessidade não atendida de planejamento familiar através de uma Análise de regressão. Os resultados mostram que todos os países têm porcentagens em declínio de necessidades não atendidas ao longo do tempo e que existe uma associação positiva entre a fertilidade decrescente e as necessidades de planejamento familiar não atendidas.

Palavras chave: planejamento familiar; Necessidades insatisfeitas; Fecundidade; Contracepção.

\section{Introducción}

Within the field of population studies, the concept of unmet need for family planning was used to explain the gap between women's fertility preferences and their use of contraception (Bradley et al., 2012). Despite the fact that modern contraception has expanded and gained 
increased legitimation in the developing world, the evidence from demographic surveys indicates that the actual family size remains greater than the size desired by women in most countries (Hakkert, 2004; Casterline \& Adams-Mendoza, 2009; McNamee, 2009; Jiménez et al., 2011; Casterline \& El-Zeini, 2014). In Latin America and the Caribbean (LAC), specifically, this gap is larger than in any other major region of the world (Hakkert, 2004; Sedgh et al., 2014). Among women in union, the percentages of total unmet need for family planning vary from $7.6 \%$ in Costa Rica to $35.0 \%$ in Haiti (UN, 2016). Additionally, estimates for 2012 show that $68.0 \%$ of pregnancies occurred in the region were unwanted (Sedgh et al., 2014).

After becoming a Millennium Development Goal (MDG) indicator in 2008, unmet need became a relevant issue among researchers and policy-makers, leading to provide compelling evidence on the aggregated benefits of expanding family planning services and supplies (Cates et al., 2010; Canning \& Schultz, 2012; Sedgh, Ashford \& Hussain, 2016). Addressing unmet need contributes to reduce the number of unintended pregnancies, induced abortions, maternal deaths, and the proportion of births at risk (Barot, 2008; Singh et al., 2009; Hogan et al., 2010; Singh et al., 2014). Also, it can prevent HIV/ AIDS transmission, reduce poverty by increasing household's savings and investment, and strengthen gender equality by promoting higher educational attainment for women and greater participation in the female labour force (Church \& Mayhew, 2009; Nattabi et al., 2009; Spaulding et al., 2009; Canning \& Schultz, 2012; Wilcher et al., 2013; Singh et al., 2014). Overall, reductions in unmet need for family planning have played a critical role in fertility decline. As demonstrated by Casterline \& El-Zeini (2014), the behaviour of fertility trends in almost every developing region responds to reductions in unmet need, meaning that fertility declines as a result of increased implementation of preferences regarding contraception.

Unmet need refers to the condition of wanting to either terminate (unmet need for limiting) or postpone (unmet need for spacing) childbearing, but not using contraception despite sexual exposure. Thus, the main purpose of operationalising this concept is to identify women's most at risk of unintended pregnancy. From a general standpoint, unmet need represents the conceptual link between concerns regarding population growth and the inability of women to achieve their reproductive aspirations autonomously (Bradley \& Casterline, 2014). At a theoretical level, the underlying idea behind this construct is the distinction between intended and unintended fertility (Ibid.).

Since fertility intentions encompass affective, cognitive, cultural and contextual dimensions, the conceptualisation and measurement of unmet need has long been a challenging task for scholars (Population Council, 2015). Indeed, the algorithm for calculating this indicator has been under continuous revision and development since the 1960s. The varying definitions of unmet need over time and the complexity of its measurement - the algorithm is derived from nearly 15 survey questions - have led to an inconsistent calculation of this indicator and, consequently, to invalid cross-country comparisons and misleading interpretation of trends (Bradley et al., 2012). In an attempt to standardise unmet need estimates, Bradley and colleagues (2012) proposed a new algorithm applied to Demographic and Health Survey (DHS) data, which produces similar (although slightly higher) levels of unmet need compared with past definitions. The latter can be calculated for surveys as early as 1990, as information collected by surveys prior to this date may include inconsistent data . Based on the standard definition of unmet need for family planning, this research aims to examine both, trends in unmet need and fertility levels in eight countries of LAC (Bolivia, Colombia, Dominican Republic, Guatemala, Haiti, Honduras, Nicaragua and Peru) from 1990 to the present. The objective is to determine to what extent variations in unmet need

${ }^{2}$ Unintended pregnancies include unplanned births, abortions and miscarriages of pregnancies.

${ }^{3}$ Indicator 5.6 for monitoring MDG 5: Improvement of maternal health. 
have contributed to achieve lower fertility levels in the countries concerned during the past two decades. Joint trends in fertility, unmet need for limiting and the proportion of demand for contraception satisfied (by any method and by modern methods, separately) are analysed using data from 32 surveys nationally representative.

\section{Background: Fertility decline in Latin America and the Caribbean and the influence of unwanted fertility}

Since the late 1960s, fertility rates have dropped sharply in most countries of Latin America and the Caribbean (LAC). Overall, the Total Fertility Rate (TFR) decreased from 6.0 children per woman in 1965 to 2.2 in 2015 (ECLAC, 2015). The specialized literature on this matter suggests that in the past few years fertility decline may have slowed or stalled in some countries of the region, especially in those where the demographic transition was completed or achieved advanced stages, as is the case of Argentina, Chile, Costa Rica, Cuba and Uruguay (Bongaarts, 2002, 2008; ECLAC, 2015). Meanwhile, countries currently experiencing full or moderate phases of this process continue to exhibit ongoing reductions in the TFR (i.e., Haiti, Bolivia and Guatemala).

The classical demographic transition theory portrays fertility decline as a consequence of industrialisation and improvements in economic and social development; thus, high outcomes of TFR would be a rational response to poverty (Thompson, 1929; Davis, 1945). According to this perspective, the drops in this component result from a decreased demand for live births, due to improved child survival and societal transformationsincluding enhanced quality of life - that lead to perceiving birth control as advantageous. As stated by some scholars (Castro- Martín \& Juárez, 1995; Zavala de Cosío, 1995; Schkolnik \& Chackiel, 2004) the former explanation fits well with the downward trends in fertility recorded in LAC during the 1960s and 1970s, mainly caused by changes in the reproductive behaviour of highly educated women from urban areas and socially privileged groups, who tended to postpone marriage and increase their demand for family-size limitation. However, empirical research aimed at analysing fertility levels in the region shows that the decreasing trends in the last five decades are not merely an adaptive reaction to demographic and economic transformations; but rather, this decline results from the spread of certain key attitudes and behaviours (e.g., increasing use of birth control technologies), irrespective of the economic status (Casterline, 2001; Schoumaker, 2004; Di Cesare, 2007). Indeed, it has been noticed that TFR decreases sharply among low-income groups when obstacles to avoid or delay pregnancy are reduced (Zavala de Cosío, 1995; Schkolnik \& Chackiel, 2004; Di Cesare, 2007; Casterline \& El-Zeini, 2014), and that the increase of contraceptive prevalence results mainly from the satisfaction of pre-existing demand (Feyisetan \& Casterline, 2000; Barber, 2007; Casterline \& El-Zeini, 2014).

Noteworthy is the fact that fertility decline proceeded at a rapid pace despite that the incidence of poverty in the region, as a whole, changed slightly since 1980. As a matter of fact, the percentage of total poverty in LAC raised from 40.5 in 1980 to 43.9 per cent in 2002; and although it dropped to 27.9 per cent by 2013, the absolute number of poor people grew from 136 to 164 million in the last forty years (ECLAC, 2013). For some scholars (Feyisetan \& Casterline, 2000; Chackiel, 2004; Di Cesare, 2007), the drops in fertility and birth rates are essentially a consequence of the capacity that regional governments have had for 1) incorporating available technology at low cost in the areas of health and medicine-thus, reducing child and infant mortality-, and 2) increasing the coverage of family planning services. In view of these considerations, it would seem that unmet need for family planning is a better explanatory factor of fertility decline than other 
development features frequently studied, such as poverty, GDP, education level, etc. Irrespective of the pace of the decline, there is broad agreement that fertility levels in the region will remain low in the forthcoming years, and will tend to converge as the demographic transition progresses (CELADE, 2014). However, a critical gap persists between actual and desired reproductive preferences, resulting in high proportions of unwanted births and pregnancies (Casterline \& Adams-Mendoza, 2009; McNamee, 2009). According to Bongaarts (1997), as countries move through the fertility transition, the trend in unwanted fertility follows an inverted U shape, with low levels of unwanted fertility in the pre-transitional stage, high rates during the first half of the transition, and reduced levels by the end of it. By extension, unmet need will be likely to rise in early and midtransition, in response to the lag between increasing demand and actual implementation for family planning (Bongaarts et al., 2012). The former pattern results from the combined effects of a rise in the duration of exposure to the risk of unwanted pregnancy, and an increase in the use of contraception as desired family size declines. The author states that the large differences observed in unwanted fertility rates among countries at the same transition phase are mainly due to the effectiveness of contraceptive use, the completion of actual fertility aspirations, and the rate of induced abortion. In opposition to the latter, a recent study by Esteve \& Florez-Paredes (2014) concluded from the analysis of 12 Latin American countries that there have been no significant variations in the desired number of children during the past two decades. Moreover, the research showed that the ideal family size was relatively homogeneous among women with different educational level.

Casterline \& Adams-Mendoza (2009) examined recent levels of unwanted fertility in 13 countries of LAC. The authors estimated that, around 2000, nearly one-third of births were unwanted, and that women experienced on average about one unwanted birth during their reproductive age. A significant proportion of unwanted births occurred in the region derive from the high incidence of early motherhood (Esteve \& Florez-Paredes; Rodríguez, 2014). Although contraceptive use has expanded in LAC among teenagers and young women, the age at first child has remain stable, a fact that is most likely related to the inefficient use of contraception (Rodríguez, 2003; Rodríguez, 2014). From a broad viewpoint, the decrease of fertility in LAC has consisted of different mixes of drops in wanted and unwanted fertility; yet, given the high heterogeneity within the region, no generalised pattern can be derived from the national trends (Casterline \& Adams-Mendoza, 2009).

The findings presented herein are based on an earlier study by Casterline \& El-Zeini (2014) aimed at examining joint trends in fertility, unintended fertility, and unmet need in the developing world from 1970 to the present. The latter empirical analysis showed that reductions in unmet need, especially unmet need for limiting, were associated with fertility decline in most regions. Particularly in LAC, a moderately strong positive association was found between the level of unmet need and the TFR ( slope $=0.1, p \leq 0.05$ ). This article delves deeper into this association, by focusing on within-country changes of unmet need and including a larger number of surveys into the analysis.

Data and Methods

This research presents findings from standardised DHS and Reproductive and Health Surveys (RHS), conducted at the national level from 1990 onwards. The selection of countries was based on the availability of at least two surveys, in order to determine the changes in unmet need over time. Overall, 32 surveys from 8 countries (Bolivia, Colombia, Dominican Republic, Guatemala, Haiti, Honduras, Nicaragua and Peru) were used for assessing the relationship between fertility decline and trends in unmet need. Data on fertility was derived from population estimates and projections by CELADE (2015) . In this study, the concept of unmet need refers to the proportion of women in union in their reproductive age, who have an unmet need for limiting family planning . In order to enable cross-national analysis, unmet need was defined according to the standard DHS algorithm, valid for surveys as early as 1990 . Hence, most of the analysis encompasses 
DHS Phases II-VI. The algorithm was applied to RHS data following the guidelines provided by Bradley et al. (2012) on the revised version of unmet need (see Appendix 1). This algorithm classifies women with an unmet need for limiting as those 1) whose current pregnancy/last birth was unwanted even if pregnancy/birth was due to contraceptive failure; 2) who are pregnant or postpartum amenorrheic and said their current pregnancy/ last birth was not wanted at all, irrespective of whether they want another child in the future; and 3) who are neither pregnant nor postpartum amenorrheic, and who do not want any more children, but are not using any contraceptive method. Infecund women are excluded, since contraceptive use among this group would have no demographic impact . Unmet need is expressed as a percentage over currently married/cohabiting women aged $15-49$, as they are assumed to be regularly exposed to the risk of pregnancy. Although unmet need among unmarried women is relatively high, studies on this matter have identified several limitations for including such women in the estimates of unmet need (Bradley \& Casterline, 2014). Unmarried women - especially the young - are likely to underreport their sexual activity, and their need for contraception may not be captured by the survey questionnaire. Nevertheless, the proportion of sexually active unmarried women is small in relation to married/cohabiting women in almost all countries and, thus, the percentages of unmet need hardly vary when sexually active unmarried women are included (Casterline \& El-Zeini, 2014).

In addition, the proportion of demand satisfied and the proportion of demand satisfied by modern methods were calculated. These two indicators perform according to contraceptive prevalence rates, regardless the changes in women's desired family-size. Consequently, the proportion of demand satisfied typically increases when contraceptive use rises, whereas the levels of unmet need can either rise or fall with changes in contraceptive use and desired family-size. For example, low levels of unmet need may reflect the fact that women want large families, and not necessarily that contraception is widely available or used (Bradley et al., 2012).

In this research, the proportion of demand satisfied is confined to the demand for limiting and was calculated as follows:

Current contraceptive use of any method

Proportion of demand for limiting satisfied $=$

Unmet need for limiting +

Current use of any method

The proportion of demand satisfied by modern methods was calculated using the same formula as above, but instead of including the use of any method in the numerator, only the use of modern methods is computed.

This article analyses the association between fertility trends and 1) unmet need, 2) demand for limiting childbearing satisfied by any method, and 3) demand for limiting childbearing satisfied by modern methods, separately, in order to avoid the problem of multicollinearity between explanatory variables. The rationale for including the demand for limiting into the analysis, besides the percentage of unmet need, responds to the fact that this indicator allows a closer approach to the extent of family planning services and contraceptive distribution among the female population who aims to control their fertility preferences. In particular, we introduce the distinction between modern and any method (which includes traditional contraception), as modern contraception is perceived to be

${ }^{5}$ CELADE - Population Division of the Economic Commission for Latin America and the Caribbean (ECLAC), 2015, available at: http://www. cepal.org/en/long-term-population-estimates-and-projections-1950-2100

${ }^{6}$ The standard algorithm of unmet need produces separate estimates for spacing and limiting family planning.

${ }_{7}^{7}$ Further information on the operational definition of unmet need can be found in Bradley, S; Croft, T.; Fishel, J.; Westoff, C. (2012) Revising Unmet Need for Family Planning. DHS Analytical Studies, No. 25, Calverton, MD: ICF International. 
more effective for reducing the risk of pregnancy. However, it must be noted that the use of traditional methods may also play an important role in fertility regulation, and they could be underreported by the DHS surveys (Cleland et al., 2014).

The relationships between fertility levels and the explanatory variables were assessed using linear regression analysis, with TFR serving as the dependent variable and the percentage of unmet need and demand satisfied (any method/modern methods) serving as the independent variables. Due to the limited number of observations included within the analysis, the regression models were examined using the data pooled across countries and surveys, treating all surveys as independent observations.

Following the assumptions pointed out by Casterline \& El-Zeini (2014) regarding the fact that 1) contraception affects fertility levels by reducing the risk of conception and, therefore, 2) that TFR should lag contraceptive prevalence by 9 months, this research estimates unmet need values for 10 months prior to the survey through linear interpolation between surveys and linear extrapolation before the first survey in each country.

Results

Table 1 illustrates the percentage distribution of unmet need for limiting family planning (\%) from 1990 onwards in selected countries. Besides the high degree of heterogeneity observed within the region, data from DHS and RHS show that unmet need levels perform, invariably, downward trends during the reference period. The highest rates of this indicator are recorded by Haiti, where the proportion of unmet need ranges from $27.7 \%$ in 1990-95 to $19.7 \%$ in 2010-15, while Colombia and Dominican Republic present the lowest levels throughout the five-year periods, fluctuating from $9.0 \%$ to $4.5 \%$ and from $10.3 \%$ to $4.0 \%$, respectively.

Tabla $\mathbf{N}^{\mathbf{0}} \mathbf{1}$ : Percentage distribution of unmet need for limiting family planning (\%) in selected countries of Latin America and the Caribbean, DHS and RHS from 1990-95 to 2010-15

\begin{tabular}{lccccc}
\hline \multicolumn{1}{c}{ Country } & $\mathbf{1 9 9 0 - 9 5}$ & $\mathbf{1 9 9 5 - 0 0}$ & $\mathbf{2 0 0 0 - 0 5}$ & $\mathbf{2 0 0 5 - 1 0}$ & $\mathbf{2 0 1 0 - 1 5}$ \\
Bolivia & 21.4 & 19.8 & 16.9 & 14 & - \\
Colombia & 9.0 & 6.6 & 5.7 & 4.9 & 4.5 \\
Dominican Rep. & 10.3 & 6.1 & 5.5 & 4.4 & 4.0 \\
Guatemala & 13.7 & 13.1 & 12.5 & 9.8 & - \\
Haiti & 27.7 & 24.0 & - & 20.8 & 19.7 \\
Honduras & - & - & - & 8.8 & 4.4 \\
Nicaragua & - & 10.5 & 9.0 & 5.2 & - \\
Peru & 15.4 & 12.2 & 7.5 & 6.2 & 5.3 \\
\hline
\end{tabular}

Sources: DHS from the DHS program (US AID); RHS from Global Health Data Exchange (GHDx)

The assessment of the associations between unmet need and TFR, on one hand, and between demand for limiting satisfied (by any/all methods) and TFR, on the other, allows answering the question whether the explanatory variables track fertility decline. From the regression analysis at the cross-country level, a significant moderately strong positive association emerges between TFR and unmet need. This latter model accounts for $61.8 \%$ of the variance $(\mathrm{p} \leq 0.05)$ (Table 2). The performance of unmet need is exposed by the slope of the line displayed in Figure 1, with a positive value (0.1) representative of the reductions in unmet need as fertility levels decrease. 
Tabla N $N^{\mathbf{2}}$ : Association between TFR and explanatory variables derived from regression models

\begin{tabular}{lccc}
\hline \multicolumn{1}{c}{ TFR and explanatory variable } & $\mathbf{R}^{2}$ & $\boldsymbol{P}$ value & Slope \\
TFR and unmet need & 0.618 & 0.05 & 0.1 \\
$\begin{array}{l}\text { TFR and demand for limiting satisfied } \\
\text { by any method }\end{array}$ & 0.642 & 0.05 & -0.5 \\
$\begin{array}{l}\text { TFR and demand for limiting satisfied } \\
\text { by modern methods }\end{array}$ & 0.500 & 0.05 & -0.3 \\
\hline
\end{tabular}

Sources: DHS from the DHS program (US AID); RHS from Global Health Data Exchange (GHDx) 1990-2015

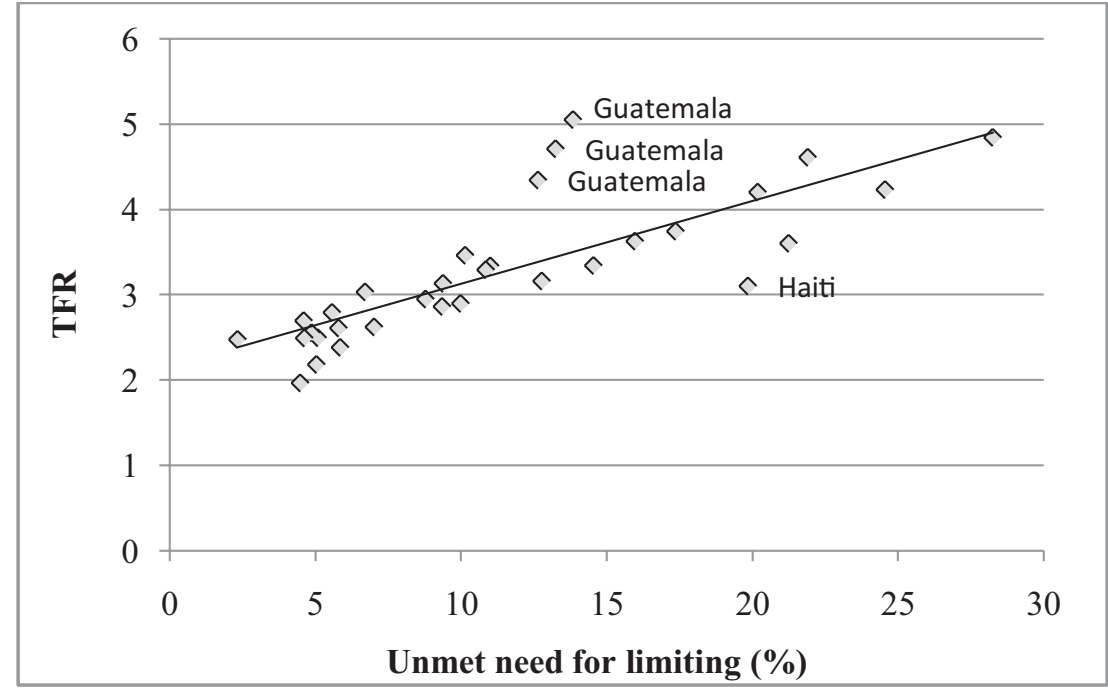

Sources: DHS from the DHS program (US AID); RHS from Global Health Data Exchange (GHDx) 1990-2015

Figure 1: Levels of unmet need for limiting family planning (\%) and TFR in eight countries of Latin America and the Caribbean

As stated by Casterline \& El-Zeini (2014), trends in fertility are, partly, a function of fertility demand. Focusing on the existence of demand, the relationship between the percentage of demand satisfied (by any method and by modern methods) and TFR was studied, confining the analysis, as above, to those women who report their intention of ending childbearing. Results show that there is a strong negative association between TFR and the percentage of demand satisfied by any method (Figure 2). As displayed in Table 2 , this model explains $64.2 \%$ of the data>s variation around its mean, and the coefficient indicates that for every additional percentage point increase in the proportion of demand satisfied by any method, we can expect TFR to increase by an average of 0.5 children per 1,000 women. Conversely, the relationship between TFR and the percentage of demand for limiting satisfied by modern methods reveals a moderate negative association (Figure $3)$, with an estimated slope of -0.3 . 


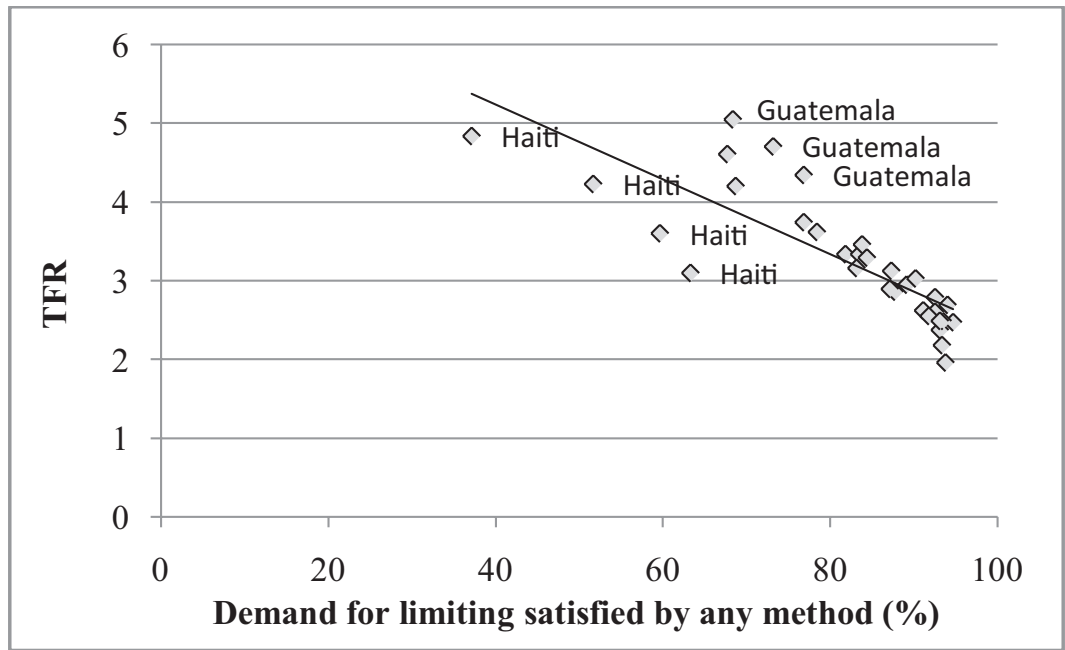

Sources: DHS from the DHS program (US AID); RHS from Global Health Data Exchange (GHDx) 1990-2015

Figure 2: Levels of demand for limiting satisfied by any method (\%) and TFR in eight countries of Latin America and the Caribbean

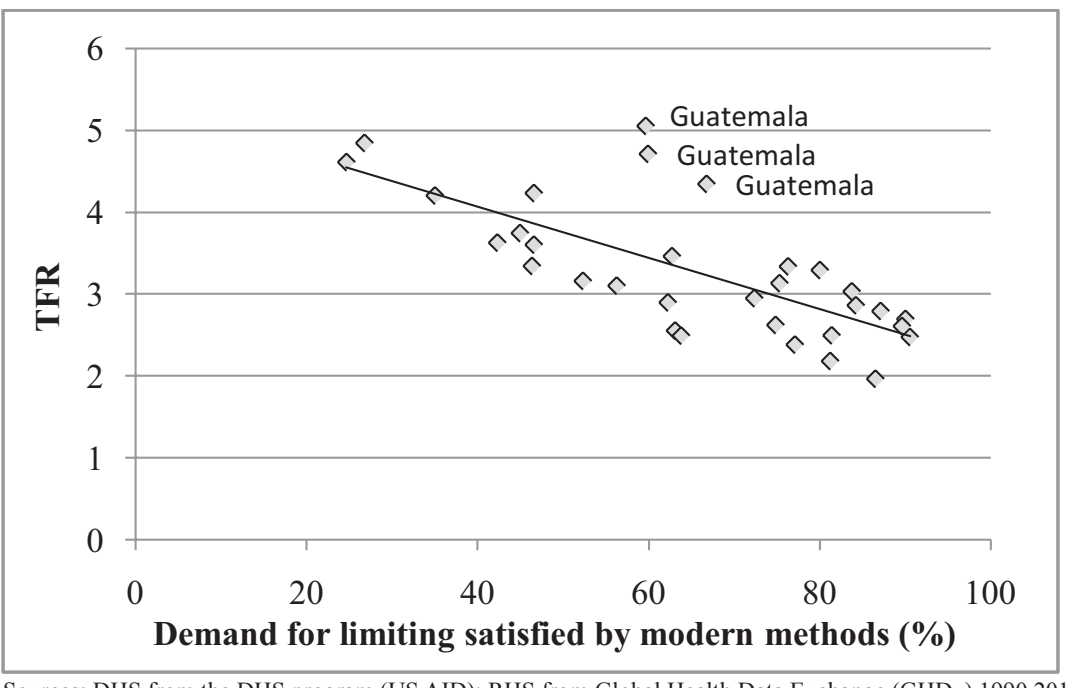

Figure: 3 Levels of demand for limiting satisfied by modern methods (\%) and TFR in eight countries of Latin America and the Caribbean

\section{Discussion}

This paper focused on the association between fertility decline and unmet need for limiting childbearing during the past two decades in countries of LAC. It emerged from the regression models that fertility decrease performs in accordance with the decline in unmet need for family planning fairly jointly in the countries concerned, as well as the increases in the proportion of demand for limiting satisfied. These results are in line with the findings exposed by Casterline \& El-Zeini (2014), who identified a fairly close association between fertility decline and unmet need for family planning in Latin American countries using a variety of indicators of both, unmet need and fertility. 
We can conclude that fertility levels decrease as a response to improved implementation of contraceptive preferences. If this is true, enhancing the access to family planning services and supplies should continue to be a top priority in the regional agenda, given the persistence of high unwanted fertility levels.

One novel aspect derived from this research, is the evidence of a systematic and widespread pattern within the region where fertility trends behave correspondingly with drops in unmet need. This pattern may be less evident in countries that are currently moving through early or intermediate stages of the demographic transition and, thus, where fertility levels are still high, as is the case of Haiti and Guatemala. Yet, we may expect converging trends as the transition progresses. These results contradict the assertion posited by some scholars (Bongaarts, 1997; Bongaarts et al., 2012) that the levels of unmet need tend to increase in early- and mid-transition stages. As shown in the percentage distribution of unmet need, no increases were recorded throughout the reference period. This applies to the different countries studied.

The analysis of unwanted fertility and its relationship with unmet need were not included in the present study. This could represent a limitation for a deeper understanding of global fertility decline, considering the impact of unintended fertility in the region and the fact that the rationale for reducing unmet need is to prevent unintended pregnancies and births. Also, this investigation assumes that the reported intentions of wanting to limit childbearing remain stable among women surveyed by the DHS and RH, which is unlikely to happen, given the fact that fertility preferences are affected by dynamic dimensions. Another possible limitation of the study is that fertility decline may respond to other factors different from improved implementation of contraception, such as changes in sexual patterns. High fertility levels may also be an outcome of inadequate or incomplete contraceptive use, instead of a consequence of unmet need and, thus, fertility decline may be a consequence of improvements in the effectiveness of contraceptive-use practices. Further, it may result from increased induced abortion (Casterline \& El-Zeini, 2014). Although the influence of these factors over fertility levels remain unknown, it is hard to imagine the performance of downward trends in this component, without conceiving increasing contraception practices.

\section{Bibliografía}

BAROT, S. (2008) Back to Basics: The Rationale for Increased Funds for International Family Planning, Guttmacher Policy Review, 11 (3): 13-18.

BONGAARTS, J. (1997) Trends in unwanted childbearing in the developing world, Studies in Family Planning, 28 (4): 267-277.

BONGAARTS, J. (2002) The End of the Fertility Transition in the Developed World, Population and Development Review, 28 (3): 419-443.

BONGAARTS, J. (2008) Fertility Transitions in Developing Countries: Progress or Stagnation? Studies in Family Planning, 39 (2): 105-110.

BONGAARTS, J.; Cleland, J.; Townsend, J.; Bertrand, J.; das Gupta, M. (2012) Family Planning Programs for the 21st Century: Rationale and Design, New York: Population Council.

BRADLEY, S. E. K.; Casterline, J. B. (2014) Understanding Unmet Need: History, Theory, and Measurement, Studies in Family Planning, 45 (2): 123-150.

BRADLEY, S. E. K.; Croft, T.; Fishel, J.; Westoff, C. (2012) Revising Unmet Need for Family Planning, DHS Analytical Studies, 25, Calverton, MD: ICF International. CANNING, D.; Schultz, P. (2012) The economic consequences of reproductive health and family planning, The Lancet, 380 (9837): 165-171

CASTERLINE, J.B. (2001) Diffusion Processes and Fertility Transition, National Research Council (US) Committee on Population, Casterline J.B., editor. Washington DC: National Academies Press. 
CASTERLINE, J.B.; Adams-Mendoza, J. (2009) Unwanted fertility in Latin America: historical trends, recent patterns.

CASTERLINE, J. B.; El $\square$ Zeini, L.O. (2014) Unmet need and fertility decline: A Comparative Perspective on Prospects in Sub-Saharan Africa, Studies in Family Planning 45 (2): $227 \square 245$.

CASTRO-MARTÍN, T.; Juárez, F. (1995) La Influencia de la Educación de la Mujer sobre la Fecundidad en América Latina: En Busca de Explicaciones, Perspectivas Internacionales en Planificación Familiar, special issue.

CATES, W. (2010) Family planning: the essential link to achieving all eight Millennium Development Goals, Contraception, 81(6): 460-1.

CELADE (2014) La nueva era demográfica en América Latina y el Caribe. La hora de la igualdad según el reloj poblacional, Documento de la Primera Reunión de la Mesa Directiva de la Conferencia Regional sobre Población y Desarrollo de América Latina y el Caribe, Santiago, 12-14 de nov.

CHACKIEL, J. (2004) La dinámica demográfica en América Latina, Serie Población y Desarrollo, 52, CEPAL/CELADE.

CHURCH, K.; Mayhew, S. (2009) Integration of STI and HIV Prevention, Care, and Treatment into Family Planning Services: A Review of the Literature, Studies in Family Planning, 40 (3): 171-186.

CLELAND, J.; Harbison, S.; Shah, I.H. (2014) Unmet Need for Contraception: Issues and Challenges, Studies in Family Planning, 45 (2): 105-122.

DAVIS, K. (1945) The World Demographic Transition, Annals of the American Academy of Political and Social Science, 237: 1-11

DICESARE, M. (2007) Patrones emergentes en la fecundidad y la salud reproductiva y sus vínculos con la pobreza en América Latina y el Caribe, Serie Población y Desarrollo, 72, UNFPA/CELADE.

ECLAC (2013) "Social Panorama of Latin America", Santiago: ECLAC.

ECLAC (2015) Long term population estimates and projections 1950-2100, Available at: http://www.cepal.org/en/long-term-population-estimates-andprojections-1950-2100

ESTEVEZ, A.; Florez-Paredes, E. (2014) Edad a la primera unión y al primer hijo en América Latina: estabilidad en cohortes más educadas, Notas de Población, 99: 39-65.

FEYISETAN, B.; CASTERLINE, J. (2000) Fertility Preferences and Contraceptive Change in Developing Countries, International Family Planning Perspectives, 26 (3): 100-109.

HAKKERT, R. (2004) Fecundidad deseada y no deseada en América Latina, con particular referencia a algunos aspectos de género, Serie Seminarios y Conferencias, 36: 267-288, Santiago de Chile: CEPAL/CELADE.

HOGAN M.C.; Foreman K.J.; Naghavi M.; Ahn S.Y.; Wang, M.; Makela, S.M. et al. (2010) Maternal mortality for 181 countries, 1980-2008: a systematic analysis of progress towards Millennium Development Goal 5, The Lancet, 375 (9726): $1609-1623$.

JIMÉNEZ, M.A.; Aliaga, L.; Rodríguez-Vignoli, J. (2011) Una mirada desde América Latina y el Caribe al Objetivo de Desarrollo del Milenio de acceso universal a la salud reproductiva, Serie Población y Desarrollo, 97, Santiago de Chile: CEPAL/CELADE

MBOUP, G.; Saha, T. (1998) Fertility Levels, Trends, and Differentials, DHS Comparative Studies, 28, Calverton, Maryland, USA: Macro International.

McNAMEE, C. (2009) Wanted and Unwanted Fertility in Bolivia: Does Ethnicity Matter?

International Perspectives on Sexual and Reproductive Health, 35 (4): 166-175. 
NATTABI, B.; Li, J.; Thompson, S.C.; Garimoi-Orach, C.; Earnest, J. (2009) A Systematic Review of Factors Influencing Fertility Desires and Intentions Among People Living with HIV/AIDS: Implications for Policy and Service Delivery, AIDS and Behavior, 13 (5): 949-968.

POPULATION COUNCIL (2015) Conceptualizing and Measuring Unintended Pregnancy and Birth: Moving the Field Forward, STEP UP Meeting Report. Accra: Population Council.

RODRÍGUEZ-VIGNOLI, J. (2003) La fecundidad alta en América Latina y el Caribe: un riesgo en transición, Serie Población y Desarrollo, 46, Santiago de Chile: CEPAL.

RODRÍGUEZ-VIGNOLI, J. (2014) La reproducción en la adolescencia y sus desigualdades en América Latina. Introducción al análisis demográfico, con énfasis en el uso de microdatos censales de la ronda de 2010, Colección Documentos de Proyecto, Santiago de Chile: CEPAL.

SCHKOLNIK, S.; Chackiel, J. (2004) Los sectores rezagados en la transición de la fecundidad en América Latina, Revista de la CEPAL, 83, 2004.

SCHOUMAKER, B. (2004) Poverty and Fertility in Sub-Saharan Africa: Evidence from 25 countries, Population Association of America Meeting, Boston, April 1-3, Available at: http://faculty.ksu.edu.sa/drzeinab/Library/my\%20site $\% 201 / \mathrm{p} 1 \% 20$ (10).pdf

SEDGH, G.; Singh, S.; Hussain, R. (2014) Intended and Unintended Pregnancies Worldwide in 2012 and Recent Trends, Studies in Family Planning, 45 (3): 301-314. SEDGH, G.; Ashford, L.S.; Hussain, R. (2016) Unmet Need for Contraception in Developing Countries: Examining Women's Reasons for Not Using a Method, New York: Guttmacher Institute-UNFPA, Available at:

https://www.guttmacher.org/sites/default/files/report_pdf/unmet-need-forcontraception-in-developing-countries-report.pdf

SINGH, S.; Darroch, J.; Ashford, L.; Vlassoff, M. (2009) Adding It Up: The costs and Benefits of Investing in family Planning and maternal and new born health, New York: Guttmacher Institute-UNFPA, Available at: http://library.nhrc.org.np:8080/nhrc/handle/123456789/90?show=full

SINGH, S.; Darroch, J.; Ashford, L. (2014) Adding It Up: The Costs and Benefits of Investing in Sexual and Reproductive Health 2014, New York: Guttmacher Institute-UNFPA, Available at: http://www.unfpa.org/sites/default/files/pub-pdf/ Adding\%20It\%20Up-Final-11.18.14.pdf

SPAULDING, A.; Brickley, D.; Kennedy, C.; Almers, L.; Packel, L.; Mirjahangir, J. et al. (2009) Linking family planning with HIV/AIDS interventions: a systematic review of the evidence, AIDS, 23 (1): 79-88.

THOMPSON, W.S. (1929), Population, American Journal of Sociology, 34 (6): 959-975.

UNITED NATIONS (2016) Millennium Development Goals Database, Available at: http://data.un.org/Data.aspx?q=unmet+need+for+family+planning\&d=MDG\& $\mathrm{f}=$ seriesRowID\%3a764 [Accessed 19.02.2017].

WILCHER, R.; Hoke, T.; Adamchak, S.E.; Cates, W. (2013) Integration of family planning into HIV services: a synthesis of recent evidence, AIDS, 27 (1): 65-75.

ZAVALA DE COSÍO, M.A. (1995) Dos Modelos de Transición Demográfica en América Latina, Perfiles Latinoamericanos, 6, June. 


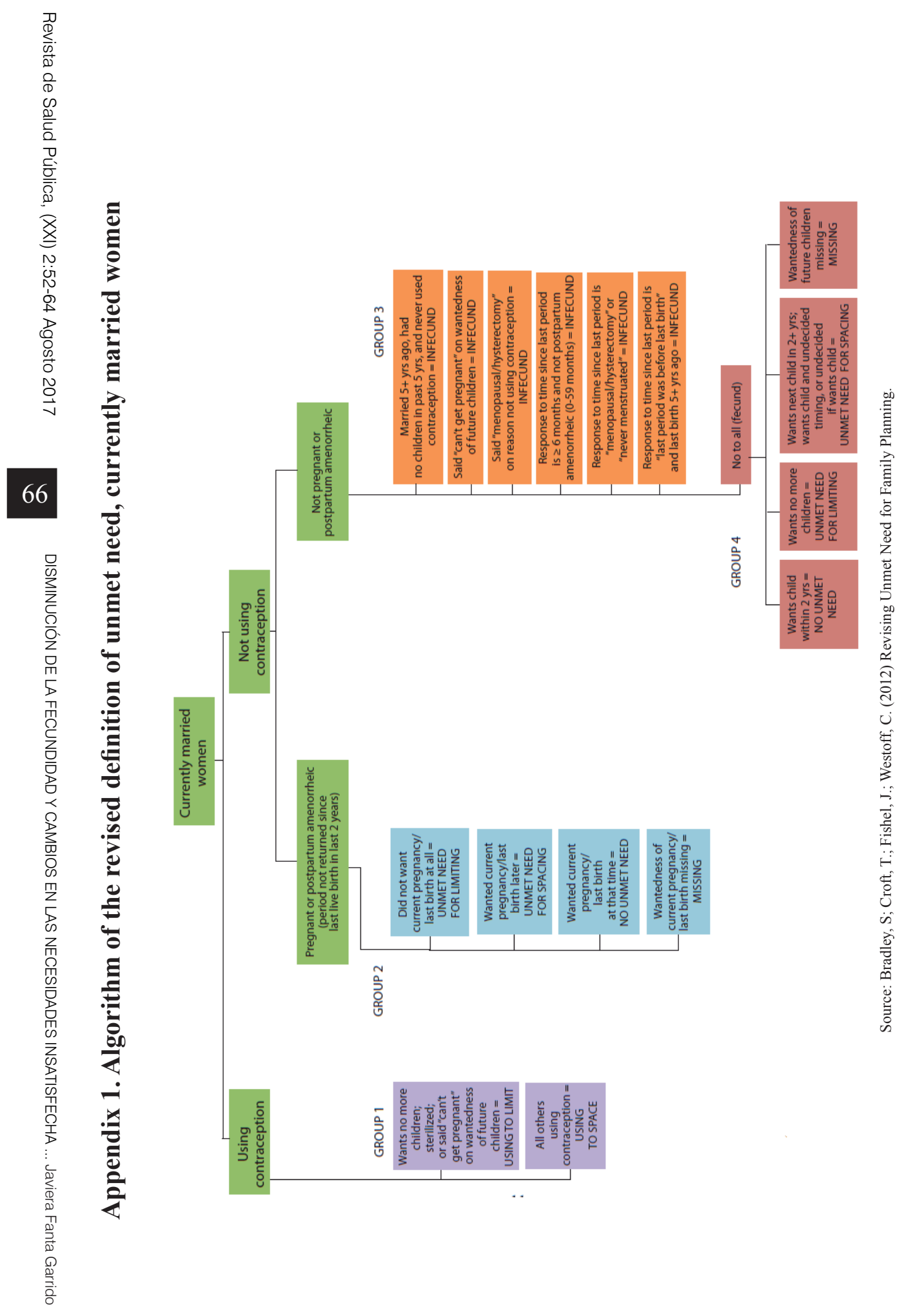

